\title{
META-ANALISIS PENGARUH PENGGUNAAN MEDIA RODA PUTAR TERHADAP HASIL BELAJAR MATEMATIKA DI SEKOLAH DASAR
}

\author{
Mar'atus Solichah $^{1}$, Akhwani $^{2}$, Sri Hartatik ${ }^{3}$, Syamsul Ghufron ${ }^{4}$ \\ 1,2,3,4 Universitas Nahdlatul Ulama Surabaya - Jl. Raya Jemursari No.57 Surabaya, 60243, Indonesia \\ maratussolichah83@gmail.com¹, akhwani@unusa.ac.id ${ }^{2}$, titax@unusa.ac.id ${ }^{3}$, syamsulghufron@unusa.ac.id ${ }^{4}$
}

\begin{abstract}
This study aims to analyze the effect of the use of the wheel media on student mathematics learning outcomes in elementary schools. This research uses meta-analysis method. Research data on the use of the wheel media is analyzed deeply to find the effect of the wheel media on the results of learning mathematics. This research begins by formulating research topics, exploring relevant research results for analysis. Data were analyzed using quantitative descriptive analysis. The results showed the use of the wheel media in learning mathematics in elementary schools could improve mathematics learning outcomes of elementary school students. Based on the results of the analysis of the use of the wheel media in mathematics learning in elementary schools can improve mathematics learning outcomes of elementary school students starting from the lowest $5.57 \%$ to the highest $545.67 \%$ with an average of $121.83 \%$.
\end{abstract}

Keywords: rotating wheel media, learning outcomes, primary school

\begin{abstract}
Abstrak: Penelitian ini bertujuan untuk menganalisis pengaruh penggunaan media roda putar terhadap hasil belajar matematika siswa di Sekolah Dasar. Penelitian ini menggunakan metode meta analisis. Data-data hasil penelitian penggunaan media roda putar dianalisis secara mendalam untuk menemukan pengaruh media roda putar terhadap hasil belajar matematika. Penelitian ini diawali dengan merumuskan topik penelitian, menelusuri hasil penelitian yang relevan untuk dianalisis. Data dianalisis dengan menggunakan analisis deskriptif kuantitatif. Hasil penelitian menunjukan penggunaan media roda putar pada pembelajaran matematika di Sekolah Dasar mampu meningkatkan hasil belajar matematika siswa Sekolah Dasar. Berdasarkan hasil analisis penggunaan media roda putar pada pembelajaran matematika di Sekolah Dasar mampu meningkatkan hasil belajar matematika siswa Sekolah Dasar mulai dari yang terendah 5,57\% sampai yang tertinggi 545,67\% dengan rata-rata $121,83 \%$.
\end{abstract}

Kata kunci: media roda putar, hasil belajar, sekolah dasar

Pendidikan menjadi sarana penting dalam menumbuhkembangkan generasi masa depan yang unggul, berkualitas dan mampu menghadapi tantangan zaman. Undang-Undang Nomor 20 Tahun 2003 menginstruksikan supaya pendidikan didesain dengan suasana yang menyenangkan untuk mencapai tujuan pembelajaran. Hal ini diperuntukkan supaya terciptanya peserta didik yang aktif, berpotensi dan memiliki akhlak mulia, selain itu supaya peserta didik memiliki keterampilan yang bermanfaat untuk diri sendiri, bangsa maupun negara. Guru harus mampu untuk memahami bahwa kemampuan setiap siswa itu berbeda-beda, ada beberapa siswa yang menyukai belajar sambil bermain, ada juga siswa yang menyukai belajar sambil menggunakan media pembelajaran yang menarik dan lain sebagainya. 
Berkembangnya teknologi yang begitu pesat mengakibatkan siswa cenderung tertarik menghabiskan waktu untuk bermain games daripada membaca materi pembelajaran (Akhwani, 2019). Untuk mengatasi dan mengantisipasi hal tersebut guru dituntut untuk kreatif dalam menyampaikan materi pembelajaran. Terlebih lagi pada usia Sekolah Dasar, pembelajaran sewajarnya didesain dengan menarik. Penggunakan media pembelajaran sering dijadikan alternatif untuk mengatasi kejenuhan belajar siswa. Selain membentuk suasana active learning, media pembelajaran juga dapat meningkatkan hasil belajar. Keterkaitan antara penggunaan media pembelajaran dengan hasil belajar siswa dapat dilihat ketika penyampaikan materi pembelajaran, guru menggunakan media dengan baik sehingga pembelajaran yang disampaikan oleh guru dapat diterima dengan baik oleh siswa, dan hasil belajar siswa dapat meningkat dengan baik dan optimal (Wati, 2019).

Ada banyak sekali jenis media pembelajaran, seperti media roda putar, media animasi, dan sebagainnya. Menurut Khairunnisa (2017) roda putar adalah obyek berbentuk bundar atau lingkaran yang dapat diputar. Media pembelajaran roda putar dapat dijadikan solusi guru dalam kegiatan pembelajaran. Siswa yang suka bermain tetap bermain, namun mereka bermain sambil belajar. Media roda putar dirancang berdasarkan prinsip media pembelajaran yang menarik dan menyenangkan (Sutjipto, 2011).

Gagasan roda putar dalam pembelajaran di sekolah dasar memiliki banyak keunggulan. Arsyad (2014) mengungkapkan keunggulan roda putar jika diimplementasikan dalam pembelajaran, antara lain: Menyenangkan, menghibur dan menarik untuk dilakukan. Roda putar memungkinkan akan adanya partisipasi aktif dari siswa untuk belajar. Di sisi lain Ahmadi (2011) mengungkapkan bahwa bagi siswa yang malas mengikuti instruksi pembelajaran, tujuan dari roda putar ini tidak dapat tercapai. Selain itu, jam putar juga memerlukan pengaturan waktu yang cukup.

Dengan melihat pernyataan atau fakta tersebut, dikhawatirkan media roda putar justru akan memberikan dampak negatif dalam mencapai tujuan pembelajaran. Artinya hasil belajar yang diinginkan bisa jadi tidak meningkat bahkan bisa jadi menurun. Tujuan pembelajaran akan tecarpai bagi siswa rajin, sementara itu siswa yang malas akan tetap tertinggal. Untuk menjawab dilema tersebut, perlu ada kajian mendalam terkait dengan implementasi media roda putar terhadap hasil belajar siswa sekolah dasar.

Guru seharusnya tidak asal-asalan dalam memilih dan menggunakan media pembelajaran. meskipun sudah disampaikan bahwa media roda putar memiliki banyak kelebihan, belum tentu cocok digunakan untuk semua jenjang pendidikan. Sebuah teori perlu diuji dan divalidasi untuk menemukan sebuah jawaban. Berdasarkan kondisi tersebut penelitian implementasi roda putar terhadap hasil belajar sangat diperlukan. Untuk mengetahui ada tidaknya pengaruh penggunaan media roda putar pada hasil belajar matematika di sekolah dasar akan dilakukan penelitian meta analisis yang bertujuan untuk memperoleh estimasi effect size, yaitu kekuatan hubungan ataupun besarnya perbedaan antar variabel.

\section{METODE}

Desain penelitian ini menggunakan Meta-analisis. Meta-analisis merupakan suatu teknik statistika yang mengabungkan dua atau lebih penelitian sejenis sehingga diperoleh paduan data secara kuantitatif. Menurut Anugraheni, (2018) meta analisis merupakan studi dengan cara menganalisis data yang berasal dari studi primer. Hasil analisis studi primer dipakai sebagai dasar untuk menerima atau mendukung hipotesis, menolak atau menggugurkan hipotesis yang diajukan oleh beberapa peneliti. Dengan kata lain, meta-analisis sebagai suatu teknik yang ditujukan untuk menganalisis kembali hasil-hasil penelitian yang diolah secara statistik berdasarkan pengumpulan 
data primer. Hal ini dilakukan untuk mengkaji keajegan atau ketidakajegan hasil penelitian yang disebabkan semakin banyaknya replikasi atau verifikasi penelitian, yang sering kali justru memperbesar terjadinya variasi hasil penelitian.

Dilihat dari prosesnya meta-analisis merupakan suatu studi observasional retrospektif, dalam arti peneliti membuat rekapitulasi fakta tanpa melakukan manipulasi eksperimental. Meta analisis merupakan teknik yang digunakan untuk merangkum berbagai hasil penelitian secara kuantitatif dengan cara mencari nilai effect size. Effect size adalah penggabungan dari masing-masing penelitian yang digunakan sebagai sumber data pada penelitian meta analisis, dengan melakukan teknik statistika tertentu (Dila, 2012). Jadi, dalam kegiatan penelitian meta analisis, data diperoleh dari hasil-hasil penelitian primer yang membahas permasalahan sejenis, untuk kemudian dianalisis hingga menghasilkan suatu kesimpulan umum. Data tersebut digunakan sebagai dasar untuk mendukung atau menolak hipotesis pada penelitian meta analisis.

Fokus penelitian ini adalah pembelajaran yang diselenggarakan di Sekolah Dasar. Subjek penelitiannya adalah siswa sekolah dasar yang menggunakan media roda putar pada pembelajarannya. Adapun jenjang kelasnya adalah kelas III, IV, V, VI Sekolah Dasar. Penelitian ini terbagi menjadi beberapa langkah, penelitian dimulai denga menetapkan domain penelitian yang akan dirangkum, memilih jenis publikasi yang akan dikumpulkan, mengumpulkan hasil penelitian atau literatur, mencatat data-data (variabel-variabel) penelitian, menghitung effect size per sumber atau penelitian, dan menginterpretasi rangkuman dan membuat laporan. Data dianalisis menggunakan analisis deskriptif. Penelitian ini memusatkan perhatian kepada masalah-masalah sebagaimana adanya saat penelitian dilaksanakan. Hasil penelitian yang kemudian diolah dan dianalisis untuk diambil kesimpulan.

\section{HASIL}

Domain yang ditetapkan dalam penelitian ini fokus pada penggunaan media roda putar dan hasil belajar siswa Sekolah Dasar. Terdapat enam literatur jurnal yang diperoleh sesuai dengan variabel penelitian. Pertama, artikel hasil penelitian Novia Prinsa Anggarini, Sumarno, Ervina Eka Subekti (2019) dengan judul "Model Two Stay Two Stray Berbantuan Media Roda Pintar Matematika Terhadap Hasil Belajar". Penelitian tersebut menunjukan pengaruh yang signifikan antara pretest 55,20 dan posttest 76,20.

Pada penelitian kedua, Retno Kuswari \& Rasiman (2019) meneliti tentang "Keefektifan Model Make a Match dengan Media Rorumat Matematika Terhadap Hasil Belajar Siswa”. Hasil penelitianya menunjukan pengaruh yang signifikan antara pretest 58,52 dan posttest 76,30 . Pada penelitian ketiga, Benny Sulistyo Nugroho (2017) menunjukkan bahwa "Pengaruh Penggunaan Media Roda Pengukuran Terhadap Hasil Belajar Siswa Kelas IV Materi Pengukuran Panjang SDN Lidah Wetan II/462 Surabaya" memiliki pengaruh yang signifikan antara pretest 47,25 dan posttest 64,81. Hasil penelitian lain, Pada penelitian keempat, penelitian dari Andriani, Qoriati Mushafanah, M. Yusuf Setia Wardhana (2019) menunjukkan bahwa "Media Roda Jelajah Indonesia efektif terhadap Hasil Belajar Materi Tematik" memiliki pengaruh yang signifikan antara pretest 75,4 dan posttest 79,6. Pada kondisi penelitian yang lain, penelitian kelima dari Isna Zulfa Arintasari, Intan Rahmawati, \& Sukamto (2019) menunjukkan bahwa "Media Roda Pecahan Berbantuan Model Realistic Mathematic Education (RME) pada Mata Pelajaran Matematika" memiliki pengaruh yang signifikan antara pretest 1,675 dan posttest 10,815. Pada penelitian keenam, penelitian dari Izzatul Lailah Wijayanti (2015) menunjukkan bahwa "Pengaruh Penggunaan Media Jam Terhadap Hasil Belajar Matematika Materi Pengukuran Sudut Siswa Sekolah Dasar" memiliki pengaruh yang signifikan antara pretest 48,792 dan posttest 85,000 . 
Tabel 1: Hasil Analisis Media Roda Putar

\begin{tabular}{|c|c|c|c|c|c|c|}
\hline \multirow[t]{2}{*}{ No } & \multirow[t]{2}{*}{ Topik Penelitian } & \multirow[t]{2}{*}{ Peneliti } & \multicolumn{4}{|c|}{ Peningkatan Hasil Belajar } \\
\hline & & & Pre Test & Post Test & Gain & Gain (\%) \\
\hline 1. & $\begin{array}{l}\text { Keefektifan Model Two Stay Two } \\
\text { Stray Berbantu Media Roda Pintar } \\
\text { Matematika Terhadap Hasil Belajar }\end{array}$ & $\begin{array}{l}\text { Novia Prinsa } \\
\text { Anggarini, } \\
\text { Sumarno, Ervina Eka } \\
\text { Subekti. }\end{array}$ & 55,20 & 76,20 & 21,0 & 38,04 \\
\hline 2. & $\begin{array}{l}\text { Keefektifan Model Make a Match } \\
\text { Dengan Media Rorumat Matematika } \\
\text { TerhadapHasil Belajar Siswa }\end{array}$ & $\begin{array}{l}\text { Retno Kuswari, } \\
\text { Rasiman. }\end{array}$ & 58,52 & 76,30 & $\begin{array}{c}17,7 \\
8\end{array}$ & 30,38 \\
\hline 3. & $\begin{array}{l}\text { Pengaruh Penggunaan Media Roda } \\
\text { Pengukuran Terhadap Hasil Belajar } \\
\text { Siswa Kelas IV Materi Pengukuran } \\
\text { Panjang SDN Lidah Wetan II/462 } \\
\text { Surabaya }\end{array}$ & $\begin{array}{l}\text { Benny Sulistyo } \\
\text { Nugroho. }\end{array}$ & 47,25 & 64,81 & $\begin{array}{c}17,5 \\
6\end{array}$ & 37,16 \\
\hline 4. & $\begin{array}{l}\text { Keefektifan Media Roda Jelajah } \\
\text { Indonesia terhadap Hasil Belajar } \\
\text { Materi Tematik }\end{array}$ & $\begin{array}{l}\text { Andriani, Qoriati } \\
\text { Mushafanah, M. } \\
\text { Yusuf Setia } \\
\text { Wardhana }\end{array}$ & 75,4 & 79,6 & 4,2 & 5,57 \\
\hline 5. & $\begin{array}{l}\text { Keefektifan } \text { Media Roda Pecahan } \\
\text { Berbantu Model Realistic } \\
\text { Mathematic Education (RME) pada } \\
\text { Mata Pelajaran Matematika } \\
\end{array}$ & $\begin{array}{l}\text { Isna Zulfa Arintasari, } \\
\text { Intan Rahmawati, } \\
\text { Sukamto. }\end{array}$ & 1,675 & 10,815 & 9,14 & 545,67 \\
\hline 6. & $\begin{array}{l}\text { Pengaruh Penggunaan Media Jam } \\
\text { Terhadap Hasil Belajar Matematika } \\
\text { Materi Pengukuran Sudut Siswa } \\
\text { Sekolah Dasar }\end{array}$ & $\begin{array}{l}\text { Izzatul Lailah } \\
\text { Wijayanti. }\end{array}$ & 48,792 & 85,000 & $\begin{array}{c}36,2 \\
08\end{array}$ & 74,20 \\
\hline & Rata-Rata Efektivitas Media & Roda Putar & 47,81 & 65,45 & $\begin{array}{c}17,6 \\
48 \\
\end{array}$ & 121,83 \\
\hline
\end{tabular}

Berdasarkan hasil penelitian meta analisis pada tabel 1 dapat dilihat bahwa media roda putar sangat berpengaruh digunakan pada siswa Sekolah Dasar. Hal ini terbukti dari meningkatnya hasil belajar matematika siswa dari yang nilai rendah sampai nilai tinggi yaitu 5,57\% dan 545,67\%. Peningkatan hasil belajar tersebut dapat mempengaruhi nilai rata-rata. Terlihat dari yang sebelum menggunakan media roda putar yaitu 47,81 dan sesudah menggunakan media roda putar yaitu 65,45.

Tabel 2: Paired Samples Statistics

\begin{tabular}{ccccc}
\hline & Mean & N & Std. Deviation & Std. Error Mean \\
\hline Pretest & 47.81 & 6 & 24.740 & 10.100 \\
Posttest & 65.45 & 6 & 27.572 & 11.256 \\
\hline
\end{tabular}

Tabel 2 di atas menunjukkan bahwa pembelajaran matematika di Sekolah Dasar (SD) menggunakan media roda putar mengalami peningkatan rata-rata sebelum dan sesudah menggunakan media roda putar dari rata-rata 47,81 menjadi 65,45 .

Tabel 3: Paired Samples Test

\begin{tabular}{|c|c|c|c|c|c|c|c|c|}
\hline & \multirow[t]{2}{*}{ Mean } & \multirow{2}{*}{$\begin{array}{c}\text { Std. } \\
\text { Deviation }\end{array}$} & \multirow{2}{*}{$\begin{array}{c}\text { Std. } \\
\text { Error Mean }\end{array}$} & \multicolumn{2}{|c|}{$\begin{array}{l}\text { 95\% Confidence Interval } \\
\text { of the Difference }\end{array}$} & \multirow[t]{2}{*}{$\mathrm{t}$} & \multirow[t]{2}{*}{$\mathrm{df}$} & \multirow[t]{2}{*}{ Sig (2-tailed) } \\
\hline & & & & Lower & Upper & & & \\
\hline $\begin{array}{l}\text { Pretest - } \\
\text { Posttes }\end{array}$ & -17.648 & 11.036 & 4.505 & -29.230 & -6.066 & -3.917 & 5 & .011 \\
\hline
\end{tabular}


Tabel 3 menunjukkan adanya relasi hasil uji hipotesis, $\mathrm{HO}=$ tidak terdapat perbedaan yang signifikan terhadap hasil belajar matematika siswa sebelum menggunakan media roda putar dan sesudah menggunakan media roda putar dan $\mathrm{H} 1=$ terdapat perbedaan yang signifikan hasil belajar matematika siswa sebelum menggunakan media roda putar dan sesudah menggunakan media roda putar. Dari tabel 3 tampak bahwa nilai sig 2 tailed $(0,011)<(0.05)$. Jadi dapat disimpulkan bahwa terdapat perbedaan signifikan hasil belajar matematika siswa sebelum dan sesudah menggunakan media roda putar. Pada hasil analisis data tentang pengaruh penggunaan media roda putar untuk meningkatkan hasil belajar siswa dapat kita ambil kesimpulan bahwa pembelajaran matematika menggunakan media roda putar sangat berpengaruh di gunakan dalam kegiatan pembelajaran. Dengan menggunakan media roda putar hasil belajar siswa akan mengalami peningkatan, hal ini terbukti dari nilai rata-rata yang sebelum menggunakan media roda putar dan sesudah menggunakan media roda putar. Pada analisis terdapat presentase yang berbeda-beda dari yang terendah hingga tertinggi. Perbedaan tersebut dipengaruhi oleh berbagai faktor diantaranya faktor internal dan faktor eksternal pada siswa. Faktor internal adalah faktor yang berasal dari diri individu siswa itu sendiri, seperti halnya kemampuan kognitif, cara berfikir, kemampuan minat dan bakat, serta kesehatan. Sedangkan faktor eksternal adalah faktor yang berasal dari luar diri individu itu sendiri, seperti lingkungan sekolah, keluarga, teman sebaya, kondisi sekolah, letak sekolah, waktu, dan subjek penelitian.

\section{PEMBAHASAN}

Media pembelajaran bukanlah hal baru dalam dunia Pendidikan. Guru umumnya menggunakan media pembelajaran untuk mencapai hasil yang diinginkan. Ada banyak sekali jenis media pembelajaran, misalnya media gambar, bagan, model, film, video, komputer dan sebagainya (Prasetyo, 2018). Pemanfaatan media pembelajaran digunakan sebagai sarana komunikasi antara guru dengan siswa. Dalam media pembelajaran terdapat proses penyampaian pesan dari pendidik kepada anak didik. Media pembelajaran merupakan salah satu alat komunikasi yang digunakan dalam proses pembelajaran sehingga merangsang pikiran, perhatian serta minat belajar.

Penggunaan media semestinya disesuaikan dengan kebutuhan pembelajaan. Tidak semua materi dapat menggunakan media yang sama. Menurut Suryani (2018) media pembelajaran merupakan sarana penyampaian informasi yang dibuat atau dipergunakan sesuai dengan teori pembelajaran, dapat digunakan untuk tujuan pembelajaran dalam menyalurkan pesan, merangsang pikiran, perasaan, perhatian, dan kemauan siswa sehingga dapat mendorong terjadinya proses belajar yang disengaja, bertujuan, dan terkendali.

Roda putar sebagai media pembelajaran merupakan salah satu inovasi dalam pembelajaran. Roda putar dijadikan sebagai alat untuk mencapai tujuan pembelajaran. Media pembelajaran roda putar berbentuk lingkaran bergambar yang diputar, bergerak pada porosnya hingga berhenti disalah satu bagian gambar (Noni, 2016). ROTAR (Roda Putar) adalah suatu alat yang berbentuk bundar yang bisa bergerak dan dapat berputar-putar atau berkeliling yang dapat digunakan sebagai media pembelajaran. Disamping itu media ROTAR ini dapat menyajikan pesan atau informasi mengenai mata pelajaran yang akan disampaikan. Media ROTAR ini juga termasuk media yang menarik, sehingga dengan menggunakan media ROTAR ini, siswa dapat tertarik dan semangat untuk belajar dan lebih mudah dalam memahami pelajaran yang disampaikan oleh guru.

Menurut Arsyad (2011) ROTAR memiliki banyak manfaat jika digunakan dalam pembelajaran. Guru tidak perlu menghabiskan waktu lama untuk menjelaskan materi pembelajaran dan dapat menarik perhatian siswa, sehingga siswa termotivasi dalam mengikuti kegiatan pembelajaran yang sedang berlangsung. Selain itu siswa menjadi tertarik dan semangat mengikuti 
proses pembelajaran. Pernyataan ini sejalan dengan manfaat media pembelajaran yang disampaikan oleh Sanaky (2013) bahwa pemanfaatan media pembelajaran selaian memberikan dan meningkatkan variasi belajar, memberikan inti informsi dan pokok-pokok secara sistematis sehingga memudahkan proses belajar, merangsang siswa untuk berpikir dan beranalisis, menciptakan kondisi dan situasi belajar tanpa tekanan, siswa dapat memahami materi pelajaran dengan sistematis yang disajikan melalui media pembelajaran.

Pemanfaatan media roda putar pada pembelajaran siswa di sekolah dasar dapat dijadikan pilihan. Siswa sekolah dasar yang pada dasarnya suka bermain diajak untuk belajar sambil bermain. Guru memberikan suasana belajar yang menarik, siswa terlibat secara langsung dalam proses pembelajaran. Proses belajar yang baik akan sangat mempengaruhi hasil belajar. Media roda putar banyak dimanfaatkan untuk meningkatkan hasil belajar siswa, karena memiliki banyak kelebihan.

Salah satu keberhasilan guru dalam pembelajaran adalah ketika ada perubahan positif pada peserta didik. Hal ini dapat diwujudkan melalui hasil belajar. Beragam cara yang dilakukan guru supaya pembelajaran mampu mencapai atau sesuai tujuan pembelajaran. Penggunaan roda putar mejadi salah satu cara supaya hasil belajar siswa dapat meningkat. Implementasi roda putar dalam pembelajaran telah banyak digunakan di sekolah. Khususnya pada jenjang sekolah dasar, roda putar bukan media yang asing lagi.

Latar belakang penggunaan roda putar berbeda-beda, media pembelajaran memiliki kedudukan yang sangat penting dan memberikan pengaruh besar dalam proses pembelajaran, diantaranya untuk menciptakan suasana pembelajaran yang aktif, kreatif, inovatif, efektif dan menyenangkan. Guru dituntut untuk menciptakan media pembelajaran yang dapat membangkitkan minat belajar peserta didik. Namun kenyataannya masih banyak guru yang belum memanfaatkan media pembelajaran secara maksimal pada saat menjelaskan materi ajar dalam pembelajaran. Menurut Prastowo (2013) pelaksanaan pembelajaran membutuhkan media pembelajaran yang variatif dan tidak monoton.

Setiap media pengajaran memiliki keampuhan masing-masing maka diharapkan kepada guru agar menentukan pilihannya sesuai dengan kebutuhan pada saat suatu kali pertemuan. Hal ini dimaksudkan jangan sampai penggunaan media menjadi penghalang proses belajar mengajar yang akan guru lakukan di kelas. Memilih media yang akan digunakan harus berdasarkan maksud dan tujuan pemilihan yang jelas. Setiap media mempunyai karakteristik tertentu, baik dilihat dari segi keampuhannya, cara pembuatannya maupun cara penggunannya. Media pembelajaran menentukan hasil belajar, keberhasilan menggunakan media pembelajaran pembelajaran dalam proses pembelajaran untuk meningkatkan hasil belajar tergantung pada isi, cara menjelaskan apa maksud media tersebut, dan karakteristik peserta didik dalam menerima maksud materi yang ada di dalam media tersebut.

Proses pembelajaran yang dilakukan secara sederhana tidak akan memberikan pengalaman bermakna pada peserta didik, maka peneliti memberikan alternatif untuk memecahkan masalah tersebut yaitu dengan cara menggunakan media pembelajaeran berupa media roda putar. Proses pembelajaran yang dilakukan secara verbal atau sederhana saja tidak akan memberikan pengalaman bermakna pada peserta didik, maka dibutuhkan media pembelajaran yang terintegrasi. Pelaksanaan proses pembelajaran di sekolah seorang guru hendaknya mampu memilih dan mendayagunakan media pembelajaran yang sesuai dengan materi pembelajaran. Pada umumnya guru jarang menggunakan media pembelajaran dalam setiap proses pembelajaran, karena kurangnya pemahaman guru terhadap media-media pembelajaran yang dapat memudahkan guru dalam pelaksanaan proses pembelajaran di kelas. 
Dengan demikian dalam memilih dan menggunakan media perlu diperhatikan faktor tersebut. Berbagai manfaat media adalah menarik perhatian peserta didik, membuat peserta didik lebih fokus dalam belajar, dan memotivasi peserta didik dalam melakukan proses pembelajaran. Guru merupakan sopir bagi peserta didik kemana guru akan membawa peserta didik tersebut, apabila diajak ketempat yang enak peserta didik juga akan merasa enak begitu pula sebaliknya. Jadi intinya guru harus selalu kreatif dan inovatif dalam menciptakan suasana kelas dan mengembangkan media yang menarik agar peserta didik di dalam kelas merasa nyaman dan senang. Apabila faktor tersebut sudah dilakukan dalam pembelajaran tentunya akan memberikan hasil yang maksimal.

Hasil penelitian menunjukan ada perubahan yang positif. Dari keenam penelitian tidak ada yang menunjukkan hasil yang buruk antara sebelum dan sesudah menggunakan media roda putar. Semua memberikan hasil yang bagus, dengan variasi yang berbeda.

Pada hasil penelitian yang sudah dianalisis terdapat selisih yang berbeda-beda, ada yang selisih tinggi ada juga yang selisih sedikit, menurut hasil penelitian terdapat perbedaan antara satu dengan yang lain pada peserta didik di Sekolah Dasar. Perbedaan ini menyangkut kapasitas intelektual, ketrampilan, motivasi, persepsi, sikap, kemampuan, minat, dan latar belakang keluarganya. Kesulitan yang dialami pada pembelajaran adalah pengetahuan peserta didik yang berbeda-beda sedangkan proses pembelajaran membutuhkan pengetahuan dan pengalaman yang banyak. Faktor pendukung peserta didik yaitu komunikasi, kerjasama dan diskusi. Guru merupakan sopir bagi peserta didik kemanapun guru akan membawa peserta didik tersebut, apabila guru mengajak peserta didik ketempat yang enak peserta didik juga akan merasa enak begitu pula sebaliknya. Jadi intinya guru harus selalu kreatif dan inovatif dalam menciptakan suasana kelas dan mengembangkan media yang menarik agar peserta didik di dalam kelas merasa nyaman dan senang.

Dengan menggunakan media roda putar hasil belajar siswa akan mengalami peningkatan, hal ini terbukti dari nilai rata-rata yang sebelum menggunakan media roda putar dan sesudah menggunakan media roda putar. Pada hasil analisis di atas terdapat presentase yang berbeda-beda dari yang terendah hingga tertinggi. Perbedaan tersebut dipengaruhi oleh berbagai faktor diantaranya faktor internal dan faktor eksternal pada siswa. Faktor internal adalah faktor yang berasal dari diri individu siswa itu sendiri, seperti halnya kemampuan kognitif, cara berfikir, kemampuan minat dan bakat, serta kesehatan. Sedangkan faktor eksternal adalah faktor yang berasal dari luar diri individu itu sendiri, seperti lingkungan sekolah, keluarga, teman sebaya, kondisi sekolah, letak sekolah, waktu, dan subjek penelitian.

Dalam proses pembelajaran, tujuan digunakan media adalah untuk menjadikan proses pembelajaran dan hasil belajar mengajar lebih berdaya dan berhasil serta menimbulkan semangat belajar peserta didik untuk meningkatkan hasil belajar. Jadi, penggunaan media yang tepat akan mencapai tujuan yang diinginkan (Sanaky, 2013). Pernyataan ini sangat mendukung dari hasil-hasil penelitian tentang pengaruh roda putar terhadap hasil belajar siswa di sekolah dasar.

Adapun tujuan penerapan media roda putar ini secara umum adalah untuk mendorong siswa berfikir aktif, melatih percaya diri yaitu dengan berbicara dan mengemukakan pendapatnya, melatih daya ingat peserta didik dan mendengar pendapat orang lain serta bertanggungjawab dan bekerjasama (Riyani, 2019). Berdasarkan tujuan tersebut, maka dengan penerapan media ini peserta didik dilatih untuk berfikir kritis, kreatif dan percaya diri dalam memecahkan masalah serta membangun rasa saling menghargai pendapat orang lain.

Dalam penerapan media roda putar dilakukan dengan sintak yang variative, secara garis besar dimulai dengan memilih tema atau materi ajar yang akan disampaikan menggunakan media roda putar. Guru memberikan penjelasan tentang materi yang akan diajarkan sebagai bekal siswa sebelum menggunakan media roda putar. Satu set kartu dengan berbagai macam pertanyaan dan diberi angka 
dibelakangnya. Kemudian membuat "Roda Putar" dari karton atau kardus, bagi roda menjadi sektorsektor sejumlah kartu pertanyaan dan beri angka pada sektor tersebut, buat pemutar dari anak panah kardus atau karton dan paku pines, hasil akhirnya nampak mirip roda. Kemudian peserta didik duduk dalam lingkaran besar dan kartu disebar menghadap ke bawah menutupi lantai dengan angka jelas terlihat,satu sukarelawan mulai ambil roda dan putar, angka ditunjukkan.

Dalam implementasi pembelajaran, siswa tersebut berdiri mengambil kartu sesuai dengan angka di roda dan menjawab pertanyaan yang ada, diskusi singkat berlangsung antara guru dan seluruh peserta didik, jika mereka memutuskan bahwa siswa tersebut telah menjawab dengan lengkap dan akurat, kartu diletakkan kembali menghadap ke atas, angka itu sekarang hangus, jika jawaban tidak lengkap atau tidak benar maka kartunya dikembalikan menghadap ke bawah untuk orang lain yang mencoba kesempatannya dan roda diberikan untuk siswa selanjutnya, begitu waktu berlalu lebih bnyak kartu terbuka. Saat angka yang hangus muncul, pemain hanya perlu memberikan roda ke peserta didik berikutnya mereka bebas, jadi permainan semakin cepat.

\section{SIMPULAN}

Dapat disimpulkan bahwa pembelajaran dengan media roda putar sangat berpengaruh digunakan pada siswa Sekolah Dasar. Hal ini terbukti dari meningkatnya hasil belajar siswa di Sekolah Dasar. Meningkatnya hasil belajar siswa dapat dilihat dari hasil nilai rata-rata sebelum menggunakan media roda putar (Pretest $=47,81$ ) dan setelah menggunakan media roda putar (Posttest $=65,45)$. Selisih dari rata-rata pretest dan posttest adalah 121,83\%.

\section{DAFTAR RUJUKAN}

Ahmadi, I. K., Amri, S., \& Elisah, T. (2011). Strategi pembelajaran sekolah terpadu. Jakarta: Prestasi Pustaka.

Akhwani, A. (2019). Strategy Of Digital Etiquette Education Of Elementary School Students. PrimaryEdu-Journal of Primary Education, 3(2), 43-54.

Andriani, A., Mushafanah, Q., \& Wardhana, M. Y. S. (2019). Keefektifan Media Roda Jelajah Indonesia terhadap Hasil Belajar Materi Tematik. International Journal of Elementary Education, 3(2), 194-201.

Anggarini, N. P., Sumarno, S., \& Subekti, E. E. (2019). Keefektifan Model Two Stay Two Stray Berbantu Media Roda Pintar Matematika Terhadap Hasil Belajar. Janacitta, 2(1).

Anugraheni, I. (2018). Meta Analisis Model Pembelajaran Problem Based Learning dalam Meningkatkan Keterampilan Berpikir Kritis di Sekolah Dasar [A Meta-analysis of ProblemBased Learning Models in Increasing Critical Thinking Skills in Elementary Schools]. Polyglot: Jurnal Ilmiah, 14(1), 9-18.

Arintasari, I. Z., Rahmawati, I., \& Sukamto, S. (2019). Keefektifan Media Roda Pecahan Berbantu Model Realistic Mathematic Education (RME) pada Mata Pelajaran Matematika. International Journal of Elementary Education, 3(4), 366-372.

Arsyad, A. (2014). Media Pembelajaran (edisi ke-17). Jakarta: PT. Raja Grafindo Persada.

Dila, K. A. S. (2012). Telaah Kritis Artikel Review Sistematik Dan Meta Analisis.

Khairunnisa, W. (2017). Pengembangan Media Permainan Roda Putar Berbasis Website Untuk Keterampilan Membaca Bahasa Prancis Siswa Kelas XI SMA AngkasaAdisutjipto. Skripsi. Jurusan Pendidikan Bahasa Prancis Universitas Negeri Yogyakarta.

Kuswari, R. (2019). Keefektifan Model Make A Match Dengan Media Rorumat Matematika Terhadap Hasil Belajar Siswa. Mimbar Ilmu, 24(1), 20-27.

Riyani, I. (2019). Pengaruh Penggunaan Alat Peraga Roda Putar Terhadap Hasil Belajar Matematika Siswa Kelas Iv Sd Negeri 56 Kota Bengkulu (Doctoral dissertation, IAIN BENGKULU).

Sanaky, H. A. (2013). Media pembelajaran interaktif-inovatif. Yogyakarta: Safiria Insania 
Sulistyo N, B. E. N. N. Y. (2017). Pengaruh Penggunaan Media Roda Pengukuran Terhadap Hasil Belajar Siswa Kelas Iv Materi Pengukuran Panjang Sdn Lidah Wetan Ii/462 Surabaya. Jurnal Penelitian Pendidikan Guru Sekolah Dasar, 5(3).

Wijayanti, I. L. (2015). Pengaruh Penggunaan Media Jam Terhadap Hasil Belajar Matematika Materi Pengukuran Sudut Siswa Sekolah Dasar. Jurnal Penelitian Pendidikan Guru Sekolah Dasar, 3(2). 